The Right(s) and minimum income in hard times:

Southern and Eastern Europe compared

Marcello Natilia*, Matteo Jessoula ${ }^{\mathrm{a}}$, Ilaria Madama ${ }^{\mathrm{a}}$ and Manos

Matsaganis $^{\mathrm{b}}$

${ }^{a}$ Department of Social and Political Sciences, University of Milan, Italy; ${ }^{b}$ Department of Architecture and Urban Studies, Polytechnic University of Milan, Italy

* Department of Social and Political Sciences,

Via Conservatorio 7, 20122, Milan

Tel. +393401247168

marcello.natili@unimi.it 


\section{Biographical notes}

Marcello Natili is Post-Doctoral Fellow at the University of Milan and a member of European Social Policy Network. His publications include "Explaining different trajectories of minimum income schemes: Groups, parties and political exchange in Italy and Spain", in Journal of European Social Policy, forthcoming; "Active inclusion as an organisational challenge: integrated anti-poverty policies in three European countries" (with M. Heidenreich, N. Petzold and A. Panican), in Journal of International and Comparative Social Policy, 2014; and " $A$ farewell to universalism, a farewell to equality? The paradox of redistribution in the era of the new politics of the welfare state" (with I. Madama), in Politiche Sociali/Social Policies, 2016. In 2015 he won the Young Researcher Award of the journal Politiche Sociali/Social Policies.

Matteo Jessoula is Associate Professor of Political Science at the University of Milan, Director of the Welfare Laboratory at Centro Einaudi, Turin and a member of European Social Policy Network. Among his publications, the volumes: Fighting poverty and Social Exclusion in the EU. A Chance in Europe 2020, Routledge, 2018 (co-edited with I. Madama), Labour Market Flexibility and Pension Reforms. Flexible Today, Secure Tomorrow?, Palgrave, 2012 (co-edited with K. Hinrichs); and the articles: "Selective flexicurity" in segmented labour markets: the case of Italian mid-siders (with P. Graziano and I. Madama) in "Journal of Social Policy", 2010; "Europe 2020 and the Fight against Poverty: Beyond Competence Clash, Towards 'Hybrid' Governance Solutions?", in “Social Policy \& Administration”, 2015.

Ilaria Madama is Associate Professor of Political Science at the University of Milan and Senior Researcher in the ERC project REScEU. Among her publications: Fighting poverty and Social Exclusion in the EU. A Chance in Europe 2020, Routledge, 2018 (co-edited with M. Jessoula); "Beyond continuity? Italian social assistance policies between institutional opportunities and agency", in International Journal of Social Welfare, 2013; "The Dark Side of the (Pink) Moon. The Role of Europe in the Recent Evolution of Italian Conciliation Policies" (with P. Graziano), in European Journal of Social Security, 2011.

Manos Matsaganis is Associate Professor of Public Finance at Politecnico di Milano. His recent publications include "The political economy of austerity in Southern Europe" (with S. Perez), New Political Economy, 2018; "Making sense of the Greek crisis" in Europe's crises (edited by M. Castells et al.), Polity, 2018; "The distributional impact of austerity and the recession in Southern Europe" (with C. Leventi), South European Society and Politics, 2014; and "The welfare state and the crisis: the case of Greece”, Journal of European Social Policy, 2011. 


\title{
The Right(s) and minimum income in hard times: Southern and Eastern Europe compared
}

\begin{abstract}
The paper addresses a topic still largely under-researched in comparative welfare state literature: the role of right parties in the reform of last resort safety nets. More precisely, the study investigates minimum income schemes' reforms promoted during the Great Recession (2008-2013) by centre-right governments in three countries belonging to the European periphery: Italy, Portugal and Latvia. Despite common political orientation and increased problem pressure, these countries have gone through distinct reform trajectories in their social safety nets that may be labelled expansion (Latvia), retrenchment (Portugal), and continuity (Italy). Against this backdrop, the paper suggests that right parties display substantially different positions and pursue different reform strategies in anti-poverty policies. These differences can be explained by the diverse types of right parties and varying competition and coalition dynamics in the three countries.
\end{abstract}

Keywords: Right Parties; Political Competition; Social Policy; Political Cleavages; Poverty

\section{Introduction}

Southern and Eastern European countries have traditionally displayed a peculiar combination of weak social assistance (Ferrera 2005) and high poverty, which has further increased in the context of the Great Recession and EU-driven austerity. Against this backdrop, the paper addresses a topic that remains largely under-researched in the comparative literature: the role of right parties in the reform of anti-poverty policies (Jensen 2014; Clegg 2014; Jessoula et al. 2014). Specifically, the paper investigates reforms of minimum income schemes ${ }^{1}$ pursued during the Great Recession (2008-2013)

\footnotetext{
${ }^{1}$ We adopt a strict definition of minimum income as a non-categorical scheme, providing taxfinanced means-tested income support as of right (i.e. non-discretionary), constituting a safety net of last resort for the working age population.
} 
by centre-right governments in three countries of the European periphery, in the South (Italy, Portugal) and the East (Latvia).

The paper has two aims. The first is descriptive: to provide a fine-grained analysis of the reform trajectories followed by centre-right governments in Portugal, Italy and Latvia. Country selection was mainly driven by three considerations. First, the crisis has clearly been far more severe in the European periphery (Southern and Eastern) than in the core, with higher poverty and material deprivation than in Western and Northern Europe, and hence growing problem pressure. Second, all three countries were ruled by centre-right governments during the Great Recession (2008-2013). Third, in spite of common problem pressure and political orientation, the three countries displayed substantial variation in minimum income reform that can be labelled expansion (Latvia), retrenchment (Portugal), and continuity (Italy), in the latter case persisting with a patchy and incomplete safety net.

The second aim is to explain the different patterns emerged by investigating the politics of minimum income reform. Questioning the classical left vs. right divide in social policy, the paper shows that the emergence of additional lines of conflict and competition dynamics within the centre-right camp is key to understanding policy trajectories in this policy area. We argue that different policy positions and different reform strategies can be understood in the light of diverse cleavages and coalition dynamics in the three countries.

The paper proceeds as follows. The next section briefly reviews the literature on the attitudes of right parties towards minimum income schemes. Section three presents recent trends in poverty and social exclusion in the three countries. Section four provides an account of minimum income reforms in 2008-2013. The final section 
concludes with an attempt to interpret different policy trajectories under centre-right governments rule in Italy, Latvia and Portugal.

\section{The Right and the welfare state}

The role of the Right in shaping social policies, for long rather neglected and under-researched, has recently gained attention in welfare state research (Jensen 2014; Lefkofridi and Michel 2016; Roth et al. 2017). As noted by Jensen (2014, p. 1), if "the Left was the main driver of change during the first decades of the post-War period and, hence, arguably was the interesting phenomenon to study, this is no longer the case". As mature welfare states confront global markets and societal transformations, taking the partisanship argument seriously requires a more nuanced approach to policy preferences than simply presuming that the left invariantly wants more and the right invariantly wants less. Right parties in fact may face different incentives leading them to support welfare expansion in diverse policy areas. Most notably, while for many voters the LeftRight divide remains salient in the case of labour-market programmes, life-course ones (such as old age pensions and health care) enjoy broader bipartisan support, with likely consequences on the positioning of political parties (Jensen 2014). Less attention, however, has been paid to the fact that different ideologies coexist on the right of the political spectrum (Rémond 1982), possibly embodying diverse interests, demands and attitudes vis à vis social policy(ies).

Building on this strand of the literature, the paper claims that the latter issue is particularly relevant for anti-poverty policies and minimum income schemes ${ }^{2}$. Among

\footnotetext{
${ }^{2}$ Conflicting preferences towards means-tested minimum income schemes are also present on the left of the political spectrum, as pointed out in the insider/outsider literature (Kevins 2017, Rueda 2007).
} 
different right party families ${ }^{3}$, attitudes towards social safety nets may be more nuanced than expected, and different from those towards encompassing social protection schemes - such as retirement pensions and health care. The liberal right might support minimum income as a less costly public intervention aimed to remedy market failure by protecting the "deserving poor". Similarly, means-tested schemes may resonate well with the notion of a residual welfare state favoured by conservatives (Pierson 1994), within a workfare perspective where these schemes serve as springboards for recipient activation. Even regionalist right parties may be in favour of minimum incomes, provided the schemes are administered locally and imply no territorial redistribution. In contrast, Christian democratic parties may be less supportive of social assistance, since public, rights-based, minimum income schemes pose a threat to traditional poor relief provided by charities and religious institutions (Jessoula et al. 2014). Furthermore, radical right parties, in the spirit of welfare chauvinism, may oppose minimum income on the grounds that many beneficiaries are foreign migrants (Natili 2017).

The existence of such diverse preferences regarding social assistance, especially within the Right, relates to the fact that the crucial political cleavages ${ }^{4}$ in this policy field may go far beyond class-based divisions, potentially cutting across the Left-Right divide. Two other cleavages - namely "State vs. Church" and "Centre vs. Periphery" may be especially salient for the politics of social assistance, as anti-poverty programmes tend to generate deeply rooted normative conflicts concerning who are the poor, who deserves assistance, and by whom. Along the State-Church dimension,

\footnotetext{
3 On the concept of "party family" and on the differences between liberal, conservative, Christian democratic and radical right parties, see Benoit and Laver (2006), Ennser (2012), Mair and Mudde (1998).

${ }^{4}$ Cleavages are defined as "sets of fundamental contrasts, rooted in socio-economic and cultural differences, which have come to systematically divide national communities", embodying a cultural-value dimension; an organizational dimension; and a political dimension (by means of political "translation") (Rokkan 1970).
} 
'parties of religious defence' (Manow and van Kersbergen 2009) - i.e. conservative and especially Christian democratic parties - are likely to mobilize voters across the dominant-subject divide (i.e. class) in the defence of community-based welfare institutions and traditional family ties. These parties might therefore oppose a public rights-based minimum income programme that might displace traditional last resort assistance made available by charities and religious institutions (Clegg 2014; Jessoula et al. 2014). As for the Centre-Periphery cleavage, the presence of regionalist parties may significantly affect the political viability of national anti-poverty schemes, giving rise to harsh territorial distributive conflicts (Madama 2010). Nevertheless, regionalist parties might support the institutionalization of regional minimum income schemes as part of a strategy to promote "region building" (Natili 2017).

In addition, party preferences and coalition agendas do not happen in a vacuum: they are shaped by political systems and competition dynamics. In the words of Hausermann et al. (2010, p. 9): "what parties do depends (also) on the competition they face". In the same vein, other authors (Ferrera 1993, Manow 2009) have stressed the relevance of the political cleavage structure for party competition dynamics and, ultimately, social policy outputs. In this perspective, we argue that in the field of social assistance, the political activation of either or both of the cleavages mentioned above, and/or the emergence of new radical right parties $^{5}$, render competition and coalition dynamics far more complex, affecting the scope and direction of minimum income reforms. This is especially relevant when minor (centre-right) parties, explicitly opposing minimum incomes, become pivotal for the formation of government coalitions (Green Pedersen 2001).

\footnotetext{
${ }^{5}$ On the emergence of radical right parties in Europe, see Mudde (2007) and Rydgren (2012).
} 
Against this background, we suggest that political competition and coalition dynamics are crucial to understanding minimum income reforms. In particular, we expect the presence and coalition/competition dynamics of different types of "Right(s)" (conservative, liberal, regionalist, Christian-democratic, and radical) to be key factors in explaining the diverse developments of social safety nets during the Great Recession in Italy, Portugal and Latvia.

\section{Poverty and deprivation during the Great Recession in the periphery}

By the end of 2014, the European economy as a whole had barely recovered the loss in output since the onset of the financial crisis in 2008. As seen in Table 1, GDP decline, and the corresponding fall in living standards, was still significant in countries of the European periphery.

Table 1. GDP growth (2008-2014)

\begin{tabular}{lccc}
\hline & $\mathbf{2 0 1 4 / 2 0 0 8}$ & \multicolumn{2}{c}{ from peak to trough } \\
\hline EU28 & $0.2 \%$ & $-4.4 \%$ & $2009 / 2008$ \\
\hline Italy & $-7.9 \%$ & $-8.9 \%$ & $2014 / 2007$ \\
Portugal & $-7.6 \%$ & $-8.3 \%$ & $2013 / 2008$ \\
\hline Latvia & $-2.2 \%$ & $-19.3 \%$ & $2010 / 2007$ \\
\hline Note: & Gross domestic product at market prices (chain-linked volumes). \\
Source: & Own calculations on data from the Eurostat database; GDP and main components (output, \\
& expenditure and income) [nama_10_gdp]. &
\end{tabular}

Overall, the recession was deeper and longer in Italy and in Portugal. The Baltic countries witnessed a severe but brief recession in the early years of the crisis. In the case of Latvia, the loss in output was over $19 \%$ in 2007-2010. Nevertheless, the country returned to positive rates of growth by 2010 , and recovered most of previous losses by 2014.

The distributional impact of an economic crisis may vary substantially, depending on the interaction between the (reduced) earnings of those affected, the 
income and employment status of other persons in the same households, and the capacity of the tax-benefit system to absorb macroeconomic shocks (Atkinson 2009). Moreover, distributional effects may well look different depending on the dimension considered. For example, since average living standards typically decline in a crisis, the estimated effect on poverty will be less pronounced if the relevant threshold is set as a proportion of average (or median) incomes than when it is held constant in purchasing power terms (Jenkins et al. 2013). The justification for 'anchoring' the poverty threshold is that, at times of rapid change in living standards, individuals may compare their material circumstances not only with those of 'the average person' in the society in which they live (the standard poverty indicator), but also with their own material circumstances in a previous period (in this case, before the crisis). As it turns out, 'anchoring' the poverty threshold to that of a previous year (in this case, 2008), adjusted for inflation, is exactly what Eurostat routinely does. The results of this exercise for the countries examined here are presented in Table 2.

Table 2. 'Anchored' poverty rate (2008-2013)

\begin{tabular}{llcc}
\hline & $\mathbf{2 0 0 8}$ & $\mathbf{2 0 1 3}$ & $\begin{array}{c}\text { percentage point } \\
\text { difference }\end{array}$ \\
\hline EU28 & 16.6 & 18.4 & +1.8 \\
\hline Italy & 18.7 & 25.0 & +6.3 \\
Portugal & 18.5 & 22.3 & +3.8 \\
\hline Latvia & 25.9 & 33.0 & +7.1 \\
\hline Note: & Proportion of population with income below the 'anchored' poverty threshold (60\% of \\
& median equivalised income in 2008). The figure for EU28 in 2008 actually refers to the \\
Source: & EU27 (i.e. excluding Croatia). & \\
& Eurostat database; at-risk-of-poverty rate anchored at a fixed moment in time (2008) by age
\end{tabular}

The share of population in 2013 whose income was below the standard poverty threshold ( $60 \%$ of median) of the year 2008 , adjusted for inflation, revealed a variegated pattern. In Italy, it rose to $25 \%$, in Portugal to just over $22 \%$. In Latvia, 'anchored' 
poverty peaked in 2011 at approximately 35\%, but was still significantly higher in 2013 than it was in 2008 .

'Anchored poverty' is interesting because it reveals the effects of falling incomes without confounding them with those of moving poverty thresholds (as is the case of the standard poverty rate). Nevertheless, minimum income policies, the focus of this paper, target families further down the income distribution. It is instructive, therefore, to examine changes in extreme poverty, as revealed in the share of population below a lower poverty threshold - in this case, $40 \%$ of median income. The results are shown in Table 3 . Once again, extreme poverty went up to $8 \%$ in Italy and Portugal. By contrast, after early substantial increases, extreme poverty in Latvia declined towards a similar level.

Table 3. Extreme poverty rate (2008-2013)

\begin{tabular}{lccc}
\hline & $\mathbf{2 0 0 8}$ & $\mathbf{2 0 1 3}$ & $\begin{array}{c}\text { percentage point } \\
\text { difference }\end{array}$ \\
\hline EU28 & 5.3 & 5.7 & +0.4 \\
\hline Italy & 6.7 & 8.3 & +1.6 \\
Portugal & 5.7 & 8.1 & +2.4 \\
\hline Latvia & 10.7 & 8.1 & -2.6 \\
\hline Note: & Proportion of population with income below the extreme poverty threshold (40\% of median \\
& equivalised income). The figure for EU28 in 2008 actually refers to the EU27 (i.e. \\
Source: & Excluding Croatia). & Eurostat database; at-risk-of-poverty rate by poverty threshold, age and sex (source: SILC) \\
& [ilc_li02].
\end{tabular}

Finally, the effects of the Great Recession often also showed up in the form of increases in severe material deprivation. As seen in Table 4, the indicator (calculated as the proportion of population who could not afford at least 4 out of 9 items listed in the relevant questionnaire) rose in the $\mathrm{EU}$ as a whole and remained more than one percentage point higher in 2013 than it had been in 2008. In Italy, severe material deprivation almost doubled in 2008-2013. This was no doubt driven mostly by changes 
in the share of families who could no longer make ends meet (being in arrears with rent or bills, or unable to keep their home adequately warm, or to afford a week holiday), rather than by changes in the ownership or use of durable goods (such as washing machine, or telephone, or colour TV). The increase started from one of the lowest levels in Europe, but has been persistent over the period, with the exception of a small decrease in 2011. In Portugal, severe material deprivation rose mainly in 2011-2013 (from around $8.5 \%$ to almost $11 \%$ ). In Latvia, the severe material deprivation rate went from around $19 \%$ in 2008 to $31 \%$ in 2011 , then fell to $24 \%$ in 2013 .

Table 4. Severe material deprivation rate (2008-2013)

\begin{tabular}{lccc}
\hline & $\mathbf{2 0 0 8}$ & $\mathbf{2 0 1 3}$ & $\begin{array}{c}\text { percentage point } \\
\text { difference }\end{array}$ \\
\hline EU28 & 8.5 & 9.6 & +1.1 \\
\hline Italy & 7.5 & 12.3 & +4.8 \\
Portugal & 9.7 & 10.9 & +1.2 \\
\hline Latvia & 19.3 & 24.0 & +4.7 \\
\hline Note: & Proportion of population unable to afford 4 out of 9 items listed in the questionnaire. The \\
& figure for EU28 in 2008 actually refers to the EU27 (i.e. excluding Croatia). \\
Source: & Eurostat database; severe material deprivation rate by age and sex [ilc_mddd1].
\end{tabular}

\section{Expansion, retrenchment and continuity in reform trajectories}

Before the onset of the crisis, a social assistance scheme of last resort was not in place in Italy, while Portugal and Latvia had introduced a nationwide minimum income programme in 1997 and 2003 respectively.

In this section, we first sketch the main institutional elements of the national model in each country prior to the Great Recession along three key dimensions: benefit generosity, coverage and overall expenditure. We then present a detailed analysis of policy developments under centre-right rule in 2008-2013. At the end of the section, we provide a comparative assessment. 


\section{Retrenchment in Portugal}

At the onset of the crisis, Portugal had the more robust social safety net in terms of benefit generosity, coverage and overall expenditure among the three countries (Table 5). Rendimento Mínimo Garantido, a fully-fledged minimum income scheme, was first tested as a pilot project in 1996 by a socialist government (Capucha et al. 2005; Bahle et al. 2011), and then extended nationwide in 1997. The scheme guaranteed means-tested income support to the working age population at the same level as the non-contributory social pension.

Despite later amendments, and re-labelling as Rendimento Social de Inserção (RSI), the measure was still fully operative in 2008. Spending was $0.28 \%$ of GDP, coverage was significant (around 3\% of the Portuguese population), while the average benefit amounted to $46 \%$ of the difference between claimants' incomes and the social pension, at around $€ 190$ in 2009 (Baptista and Cabrita 2009) ${ }^{6}$. According to simulations by Rodrigues (2009), the take-up rate of RSI, i.e. the ratio between actual and potential beneficiaries, ranged from $70 \%$ to $75 \%$. In addition to income support, RSI comprised a "right to inclusion", understood as a duty, on a contractual basis between the authorities and recipients, offering access to a number of services: education, training, health care, housing, and job search.

During the Great Recession, and notwithstanding the magnitude of the crisis and rapidly increasing poverty rates, expenditure on minimum incomes was significantly reduced (Jessoula et al. 2015). In March 2009, the socialist government introduced a number of job-creation incentives, named "Initiatives for Investment and Employment", including a 50\% reduction of social security contributions for employers who hired RSI

\footnotetext{
${ }^{6}$ A higher benefit was available for pregnant women and for infants aged less than one.
} 
recipients. However, the policy context was to change very quickly: under pressure from the EU to deal with Portugal's public debt and budget deficit, the ruling socialist party led by José Sócrates struck a deal with the liberal-conservative main opposition party PSD that allowed the approval of hard-hitting fiscal consolidation (Moreira et al., 2014). Concerning RSI, the package introduced stricter eligibility rules (workers who voluntarily left their job and were unemployed for less than one year lost the right to minimum income), reduction of benefit levels (less generous equivalence scale, termination of higher rates for pregnant women and people with disabilities), and stricter obligations for recipients (refusal of offers of "adequate employment" and/or "socially necessary work" led to benefit termination and an exclusion period of 24 months).

The situation worsened in later years. In 2011, Portugal applied for financial assistance from the EU, the ECB and the IMF (the so-called Troika). Financial support was made conditional on the implementation of an Economic Adjustment Programme comprising a set of measures to improve the country's fiscal position. Interestingly, these did not include further retrenchment of minimum incomes (Merisio 2014). Rather, in the $\mathrm{MoU}$ it was requested to reduce education, pensions and health expenditure (p. 6) and to "revise the unemployment insurance system to reduce the risk of long-term unemployment while strengthening social safety nets" (cf. p. 21). In a few months, the centre-left government resigned, and the 2011 general election was won by the centreright coalition of PSD and the Popular Party. The new government set in motion a major revision of RSI: the equivalence scale was made even less generous (resulting in 
lower benefits and lower thresholds for access ${ }^{7}$ ), asset requirements were made stricter, the benefit level became independent from the social pension, and an obligation to engage in socially useful work was introduced (5 hours per day, 3 days per week).

According to OECD (2014), the reforms undertaken in 2010 and 2012 led to a reduction in the number of RSI beneficiaries by roughly 50\% (from 405,000 in 2010 to 206,000 in 2014). The level of income support provided also fell: in 2010-2014, the average monthly amount of benefit per recipient household decreased from $€ 240$ to $€ 215$. Cuts and eligibility changes also affected other social benefits. For instance, from mid-2012 a lower unemployment benefit was available for new beneficiaries. In this context, in $2009-2013$ the relative poverty rate increased from $17.9 \%$ to $18.7 \%$ (the highest value registered since 2004), even though lower median incomes implied a lower poverty threshold.

\section{Expansion in Latvia}

As in other Eastern European countries (Bahle et al. 2011), before accession to the EU Latvia introduced a guaranteed minimum income scheme (GMI) that replaced the previous assortment of local government schemes providing poor relief. However, GMI provided meagre support and reached only a small fraction of the population in poverty, even on the government's own definition (1.2\% of population received GMI in 2008, compared to $5.3 \%$ living in families with income below $50 \%$ of minimum wage).

At the onset of the economic crisis in 2008 , the level of GMI was about $€ 38$ (equal to $16.2 \%$ of the relative poverty threshold) per person per month. Income disregards only concerned certain social benefits. A marginal effective tax rate of $100 \%$

\footnotetext{
${ }^{7}$ For example, the monthly threshold for a couple with two children was reduced from $€ 568$ in 2010 to $€ 374$ in 2013.
} 
applied to earnings, with the amount of benefit reduced at the same rate as labour income increased (Zasova and Zdanovica 2014, p.3). In 2004-2008, the number of GMI recipients fell rapidly from 74,700 persons $(3.2 \%$ of population) to $26,800(1.2 \%)$. At an era of fast growth, declining numbers on social assistance perhaps may not be that surprising. But another reason for falling recipient numbers was that minimum income and housing benefits (the latter since 2008) were not just administered but also financed by municipalities, although by mandate of the national government. As might be expected, this sometimes led to perverse outcomes: the incidence of GMI and housing benefits was lower in poorer municipalities, whose resources made them less able to provide such benefits.

In January 2009, as the economy plunged into deep recession, unemployment increased, and household incomes fell, the Latvian government signed a Memorandum of Understanding with the European Union. The fiscal consolidation plan provided for retrenchment in public employment and retirement pensions, but not in minimum income provision (Eihmanis 2017). The centre-right government in power since 2009, led by Valdis Dombrovskis, leader of the populist right New Era party (part of the Unity Party from 2011), took steps to reinforce the social safety net for the duration of the crisis. The policy response was prompt: a public work programme was introduced (Aslund and Dombrovskis 2012), eligibility requirements for unemployment insurance were eased, the duration of unemployment benefit was extended, and GMI expanded. Changes took 5 to 8 months to come fully into effect, after which social provision improved significantly (Harrold et al. 2012, p.125).

Specifically, conditions for access to the Guaranteed Minimum Income programme were eased, and the amount of benefit significantly increased (from $€ 38$ to $€ 53$ in January 2009 , and again to $€ 57$ for adults and $€ 64$ for children in October 2009). 
The benefit remained at that level until December 2012, while from 2013 a lower rate of $€ 50$ per month was set for both adults and children (World Bank 2013, p.6). Moreover, central government co-financing (at $50 \%$ of total spending) was introduced in October 2009, and was maintained until December 2012.

As a result of these changes, the number of GMI recipients rose rapidly, to 120,600 persons in 2010 and 121,800 in 2011 (up from 60,000 in 2009). Total spending on GMI also increased, from $€ 8.8$ million in 2009 to $€ 26.3$ million in 2010 and $€ 31.3$ million in 2011. In 2012, as the economy recovered, total spending and recipient numbers began to fall, to 94,500 and $€ 22.8$ million respectively (Cālìte et al. 2014).

\section{A patchy and incomplete safety net in Italy}

At the onset of the crisis, Italy was the biggest spender on social policy among all countries of Southern and Eastern Europe, at $27.7 \%$ of the GDP, slightly above the EU15 average (27.5\%). At the same time, it featured the weakest social safety net for the working age population. Old age and survivors benefits accounted for the largest share of social expenditure $(61 \%$, relative to a European average of $46 \%)$, whereas policy areas such as unemployment, family and children, poverty and social exclusion were significantly under-financed. In particular, social assistance spending was extremely limited, at $0.2 \%$ of total social expenditure relative to a EU average of $1.4 \%$.

Notably, the absence of a minimum income scheme for working-age, ablebodied individuals has represented one of the most distinguishing features of the Italian welfare state from a comparative perspective (Saraceno 2002; Ferrera 2005; Madama 2010). At national level, the fight against poverty has traditionally relied on categorical, 
often contributory, means-tested programmes $^{8}$ (Saraceno, 1994, Jessoula and Alti 2010, Madama 2010). National schemes were complemented by a plethora of regional and local ones for the provision of social services and income support. These schemes, however, tended to be discretionary, varied across territories, were uncertain in their delivery, and heavily affected by budgetary constraints (Fargion 1997). A key exception to the traditional inertia in this policy field was the pilot Minimum Insertion Income scheme launched in 1998, but discontinued by the incoming centre-right government in 2002 (Jessoula et al. 2014).

In 2008-2013, despite the significant increase in poverty, only minor initiatives were launched. The centre-right government led by Silvio Berlusconi, in power until 2011, cut funding transfers to regional and local authorities, i.e. the main providers of social assistance in a highly decentralized policy field. The social services fund suffered significant cuts, from $€ 469$ million in 2009 to $€ 69$ million in 2012 , undermining the maintenance of regional minimum income support schemes introduced after the termination of the national pilot programme in 2002 .

In late 2008 , to address the social implications of the economic crisis, the centreright coalition introduced Carta Acquisti (Social Card, SC) to combat severe poverty. This was a pre-paid card used to purchase food and pay for utilities, initially intended to support low-income pensioners (over 65), later extended to children below the age of 3 . The low value of SC (€40 per month), its categorical character and limited coverage, the tight eligibility criteria, and the absence of activation requirements, indicate the residual and passive (if not merely symbolic) nature of the programme.

In December 2010, in a context of growing poverty and material deprivation, the

\footnotetext{
${ }^{8}$ Minimum income protection for the elderly and the disabled is secured by two schemes, the social pension (introduced in 1969) and the means-tested invalidity allowance (1974).
} 
government proposed a second version of the Social card (SC 2.0), in the form of a pilot project implemented for one year in the 12 major cities. The main novelty of the programme, endowed with a meagre budget of $€ 50$ million, was the decision to delegate management and implementation to charities and non-profit organizations, circumventing local governments.

The proposal was short lived, due to the early fall of the government. In August 2011, the European Central Bank sent a letter to the Italian government, urging it to introduce pension and labour market reforms together with other measures ${ }^{9}$. In what has been called implicit conditionality (Sacchi 2015), these demands were backed by an implicit promise to purchase a substantial amount of Italian bonds under the Securities Market Programme in order to end financial market speculation. The acute political crisis that followed led to the resignation of the Berlusconi government in November 2011. The technocratic government of Mario Monti, in power until early 2013, amended the bill drafted by the previous government, and put forward a New Social Card (NSC), which differed significantly from the previous versions. It was non-categorical in scope, combined cash assistance with social services, reserved a key role to local governments, and provided for the activation of recipients via a personalized plan involving all household members. Moreover, NSC was much higher in value (on average $€ 331$ per household per month). Despite these innovative elements, the New Social Card was still a pilot project, implemented in 12 large Italian cities, on a budget of $€ 50$ million (as had been envisaged by the previous government). On the whole, its introduction failed to address the patchy nature of the Italian social safety net (Madama et al. 2014).

\footnotetext{
${ }^{9}$ Relevantly, in this letter no specific mention was made regarding minimum income.
} 
Table 5. Expenditure, beneficiaries, and generosity of minimum incomes (2008-2013)

\begin{tabular}{|c|c|c|c|c|c|c|}
\hline & \multicolumn{2}{|c|}{$\begin{array}{l}\text { Expenditure } \\
\text { (as \% GDP) }\end{array}$} & \multicolumn{2}{|c|}{$\begin{array}{l}\text { Number of beneficiaries } \\
\text { (as } \% \text { of population) }\end{array}$} & \multicolumn{2}{|c|}{$\begin{array}{c}\text { Benefit level } \\
\text { (as \% of poverty } \\
\text { threshold) }\end{array}$} \\
\hline & 2008 & 2013 & 2008 & 2013 & 2008 & 2013 \\
\hline Portugal & $0.28 \%$ & $0.18 \%$ & $3.2 \%$ & $2.2 \%$ & $63.8 \%$ & $43.6 \%$ \\
\hline Latvia & $0.05 \%{ }^{(\mathrm{i})}$ & $0.10 \%$ & $1.2 \%$ & $4.6 \%{ }^{\text {(ii) }}$ & $30.5 \%$ & $40.8 \%$ \\
\hline Italy ${ }^{\text {(iii) }}$ & & $0.003 \%$ & & $0.04 \%$ & & $20.0 \%$ \\
\hline
\end{tabular}

Benefit levels and poverty thresholds (at $60 \%$ of median equivalised income) for a household of two adults and two children.

Source: $\quad$ Own calculations on data from National Statistical Offices.

At-risk-of-poverty thresholds: EU-SILC survey [ilc_li01], Eurostat.

Table 5 provides an overview of total spending, beneficiary numbers and benefit levels under centre-right governments in the three countries. In Portugal, the minimum income scheme underwent severe retrenchment, reducing coverage and expenditure. In Latvia, the relevance of minimum income increased, in terms of total spending and number of recipients as well as benefit level. In Italy, the New Social Card pilot, in spite of its innovative features, failed to break with the patchy and incomplete nature of the traditional model.

Furthermore, Table 6 sums up key minimum income reforms in the three countries under centre-right governments, outlining three distinct reform patterns: retrenchment in Portugal, expansion in Latvia, and continuity with the traditional model in Italy.

Table 6. Institutional change and reform trajectories in the three countries (2008-2013)

\begin{tabular}{llll}
\hline & Legislation & Institutional change & Reform trajectory \\
\hline Portugal & Statutory & Benefit generosity and duration: & Retrenchment \\
& Decree & less generous equivalence scale (lower & \\
& generosity and lower threshold to access) & \\
& Coverage/Eligibility rules: & \\
& Stricter asset requirements \\
& Introduction of the obligation to engage in a \\
& socially useful work. Each adult beneficiary, \\
& with no impediment to work, should provide \\
& 15 hours of occupational activity for week (3 \\
& & days in order to ensure a sufficient time to & \\
\hline
\end{tabular}




\begin{tabular}{|c|c|c|c|}
\hline & & engage in job search activities). & \\
\hline Latvia & $\begin{array}{l}\text { Regulation } \\
550 / 2009 \\
\text { Regulation } \\
299 / 2010 \\
\text { Regulation } \\
913 / 2012\end{array}$ & $\begin{array}{l}\text { Benefit generosity and duration: } \\
\text { Benefit generosity was increased and new } \\
\text { complementary measures were introduced (i.e. } \\
\text { pre-school education support, health care, etc.) } \\
\text { Coverage/Eligibility rules: } \\
\text { Access to minimum income was eased }\end{array}$ & Expansion \\
\hline Italy & $\begin{array}{l}\text { Decree Law } \\
112 / 2008 \text { and } \\
\text { Law } 133 / 2008 \\
\text { Decree Law } \\
225 / 2010 \text { and } \\
\text { Law } 10 / 2011 \\
\text { Budget Laws } \\
2009 \text { and } 2010\end{array}$ & $\begin{array}{l}\text { Benefit generosity and duration: } \\
\text { increased fragmentation of the benefit system } \\
\text { (plus sharp reduction of national social funds } \\
\text { for social services) } \\
\text { Coverage/Eligibility rules: } \\
\text { differentiated and strict eligibility rules, low } \\
\text { coverage }\end{array}$ & Continuity \\
\hline
\end{tabular}

Source: Own elaboration.

\section{Making sense of dissimilar reform trajectories}

The empirical evidence presented above poses a puzzle: why was it that centreright governments, under similar problem pressure and resource constraints during the Great Recession, pursued so different strategies for minimum income reform in the three countries? The puzzle is made more intriguing by the fact that the two classical explanations do not hold here. On the one hand, functionalist explanations would have led us to expect similar institutional responses to similar problem pressure dynamics. Problem pressures, in terms of high and increasing poverty and deprivation, were in fact common in the three countries, yet reform trajectories diverged considerably. Moreover, from a functionalist perspective, we might expect more expansionary policies to emerge in those countries where social safety nets were weakest, yet a more complex pattern emerged in the three countries examined here. Guaranteed minimum income was retrenched in Portugal where it had been most highly developed, expanded in Latvia from a lower base, and continued to be unavailable in Italy, in spite of the innovations of the New Social Card.

On the other hand, classical arguments of partisan politics, according to which 
Right parties are expected to act as welfare-sceptical mirror image of the Left (see Jensen 2014), are not very helpful in interpreting policy developments in Portugal, Latvia and Italy, where reform trajectories varied significantly under centre-right governments. These different trajectories are particularly intriguing when considering that external pressures pointed in the same direction in all three cases, requiring budget cuts in core welfare sectors, such as retirement pensions, but not urging countries to adopt cost saving reforms in minimum income support. It follows that domestic politics was key.

We argue that to make sense of the different reform trajectories we ought to focus on two factors: the diverse types of right parties in government, and the presence of additional cleavages, such as Church/State and Centre/Periphery. The main features of right parties in the three countries along these dimensions are summarised in Table 7.

Our findings show that in Latvia, under Dombrovskis' New Era (a populist conservative right party), in alliance with Civic Union, (a liberal right party), minimum income for the needy was a non-contested issue, on which a consensus existed among coalition parties. The absence of a party of "religious defence", and the limited relevance of competition dynamics within the centre-right coalition (from 2011 the two parties merged in Unity) favoured the emergence of a consensus over the role of social assistance. This allowed the adoption of expansionary measures despite austerity under a Memorandum of Understanding with the Troika, helping to cushion the social impact of the Great Recession. In fact, as highlighted by Eihmanis (2017), international lenders were favourable to strengthening of the social safety net in the country.

Table 7. Reform trajectories and government composition

Reform Parties in government Presence of additional cleavages




\begin{tabular}{llll}
\hline $\begin{array}{l}\text { Latvia } \\
(2009-2014)\end{array}$ & $\begin{array}{l}\text { trajectory } \\
\text { Expansion }\end{array}$ & $\begin{array}{l}\text { New Era / Civic Union } \\
\text { (Liberal, populist, and } \\
\text { conservative) }\end{array}$ & Church/State \\
\hline $\begin{array}{l}\text { Portugal } \\
(2011-2015)\end{array}$ & Retrenchment & $\begin{array}{l}\text { PSD (Conservative) } \\
\text { and CDS-PP (Christian } \\
\text { democratic) }\end{array}$ & $\begin{array}{c}\text { Church/ State } \\
\text { and }\end{array}$ \\
\hline $\begin{array}{l}\text { Italy } \\
(2008-2011)\end{array}$ & $\begin{array}{l}\text { Continuity with } \\
\text { the traditional } \\
\text { model }\end{array}$ & $\begin{array}{l}\text { PDL (Catholic, } \\
\text { conservative and } \\
\text { nationalist right) and } \\
\text { Northern League } \\
\text { (regionalist radical right) }\end{array}$ & Centre/Periphery \\
\hline
\end{tabular}

Source: Authors' elaboration.

In contrast, in Portugal, under the rule of the conservative PSD in alliance with the Christian democratic CDS, the government exploited external demands for austerity in order drastically to retrench minimum income. Control of the social security ministry by CDS, openly opposing minimum income in favour of charities and faith-based associations, was a key factor to that outcome. Interestingly, this occurred despite the fact that the Memorandum of Understanding signed with the Troika made explicit reference to the need to strengthen the domestic anti-poverty safety net alongside structural reforms and severe austerity measures. As argued by Moury and Standry (2017, p. 672) "the centre-right government plainly took the opportunity offered by the bail-out to pass reforms it wanted all along, going further than the original deal with international lenders".

Finally, tough implicit conditionality helps understand the direction and scope of welfare reforms in the field of retirement pension and labour market policy in Italy during the Great Recession (Sacchi 2015), it did not affect last resort minimum income support. The centre-right alliance between the Pole of Freedoms (Polo delle Libertà, PDL) and the Northern League, combining the political activation of both CentrePeriphery and State-Church cleavages, proved to be crucial in preventing the modernization of the social safety net. On the one hand, the catholic component of PDL 
clearly opposed a public, rights-based minimum income scheme, emphasizing the role of traditional poor-relief measures provided by charities and religious institutions. On the other hand, the Northern League took a stand against a national minimum income programme that would result in redistribution from North to South (Jessoula et al. 2014). The divisive nature of the issue within the centre-right coalition de facto led to the preservation of the traditional patchy and incomplete model.

The paper emphasized that Catholic, liberal, regionalist and/or radical right parties cater to different constituencies and embody diverse preferences towards different social policy programs. Our findings show that this holds especially true for minimum income schemes. The internal dynamics of centre-right coalitions deserve therefore more attention than has so far been the case in welfare state research, as they help explain the scope and direction of reform. The current ascendance of the (radical) Right, in Europe and beyond, adds urgency to this task. 


\section{References}

Aslund, A. and Dombrovskis, V. (2011) How Latvia Came through the Financial Crisis, Washington D.C.: Peterson Institute for International Economics.

Atkinson, A. B. (2009) Stress-testing the welfare state in Ofstad, B., Bjerkholt, O., Skrede, K. and Hylland. A. Rettferd og politikk: festskrift til Hilde Bojer på 70- årsdagen (Justice and Politics: Festschrift for Hilde Bojer on her 70th birthday). Oslo: Emiliar Forlag.

Bahle, T., Hubl, V. and Pfeifer, M. (2011). The Last Safety Net. A Handbook of Minimum Income Protection in Europe. Bristol: The Policy Press.

Baptista, I. and Cabrita, J. (2009), Minimum Income Schemes in Portugal. A Study of National Policies, Peer Review in Social Protection and Social Inclusion and Assessment in Social Inclusion, European Commission, DG Employment, Social Affairs and Inclusion, Bruxelles.

Benoit, K. and Laver, M. (2006) Party Policy in Modern Democracies. New York: Routledge.

Cālīte, L., and Balga, L. (2014), Country Report: Latvia. European Minimum Income Network, Bruxelles.

Capucha, L., Bomba, T., Fernandes, R. and Matos, G. (2005), «Portugal-A virtuous path towards minimum income?» in Ferrera, M. (Eds.) (2005) Welfare State Reform in Southern Europe: Fighting Poverty and Social Exclusion in Italy, Spain, Portugal and Greece, London, Routledge.

Eihmanis, E. (2017) Cherry-picking external constraints: Latvia and EU economic governance, 2008-2014, European Journal of Public Policy, Published Online 29 Aug 2017.

Fargion V. (1997), Geografia della cittadinanza sociale in Italia, Bologna, Il Mulino Ferrera, M. (1993), Modelli di solidarietà, Bologna, Il Mulino.

Ferrera M. (1996), The Southern Model of Welfare in Social Europe, Journal of European Social Policy, 1, pp. 17-37. 
Ferrera, M. (2005) Welfare State Reform in Southern Europe: Fighting Poverty and Social Exclusion in Italy, Spain, Portugal and Greece, London, Routledge.

Green-Pedersen, C. (2001). Welfare State Retrenchment in Denmark and the Netherlands, 19821998: The Role of Party Competition and Party Consensus. Comparative Political Studies, 34 (9), 963-85.

Harrold, P., Santos, I. and Sinnott, E. (2012) Fiscal Sustainability, Demographic Change and Inequality: The Social Sectors from Crisis to Growth in Latvia, World Bank, Washington DC.

Hausermann, S., Picot, G. and Geering, D. (2010). Rethinking Party Politics and the Welfare State: Recent Advances in the Literature. Paper prepared for the 17th International Conference of the Council for European Studies Montréal, April 15-17, 2010.

Jensen, C. (2014). The Right and the Welfare State. Oxford: Oxford University Press

Jessoula, M. and Alti, T. (2010). Italy: un uncompleted departure from Bismarck. In B. Palier, $A$ long goodbye to Bismarck? The politics of welfare reform in continental Europe. Amsterdam: Amsterdam University Press.

Jessoula, M., Kubisa, J., Madama, I. and Zielenska, M. (2014). Understanding convergence and divergence: old and new cleavages in the politics of minimum income schemes in Italy and Poland. Journal of International and Comparative Social Policy, 30, 2, pp. 128 - 146.

Lefkofridi, Zoe, and Elie Michel. (2016) "The Electoral Politics of Solidarity: The Welfare Agendas of Radical Right.” In The Strains of Commitment: The Political Sources of Solidarity in Diverse Societies, edited by Keith Banting and William Kimlycka. Oxford: Oxford University Press.

Kevins, A. (2017) Expanding Welfare in an Age of Austerity, Amsterdam, Amsterdam University Press

Madama, I. (2010) Le politiche di assistenza sociale. Bologna: Il Mulino. 
Madama I., Jessoula M. and Natili M. (2014), Minimum income: the Italian trajectory, LPF Working Paper 1/2014, Torino, Centro Einaudi.

Mair, P. and Mudde. C. (1998) 'The Party Family and its Study', Annual Review of Political Science 1: 211-29.

Manow, P. (2009) Electoral rules, class coalitions and welfare state regimes, or how to explain Esping-Andersen with Stein Rokkan, Socio-Economic Review (2009) 7, 101-121.

Manow, P. and van Kersbergen, K. (2009). Religion, Class Coalitions and Welfare States. NewYork: Cambridge Unviersity Press.

Merisio S. (2014), Adjusting The Adjustment Programmes. International Financial Assistance During The Crisis: Shaping The IMF Template To Fit The Euro Area Countries. LPF Working Paper 8/2014, Centro Einaudi.

Moury, K. and Standring, A. (2017) Going beyond the Troika': Power and discourse in Portuguese austerity politics, European Journal of Political Research 56: 660-679.

Mudde, C. (2007) Populist Radical Right Parties in Europe, Cambridge, Cambridge University Press.

Natili, M. (2017) Explaining different trajectories of minimum income schemes: Groups, parties and political exchange in Italy and Spain, Journal of European Social Policy, First Published September 13, 2017

Pierson, P. (1994) Dismantling the Welfare State. Reagan, Thatcher, and the Politics of Retrenchment, Cambridge: Cambridge University Press.

Rémond, R. (1982) Les Droites en France, Paris: Aubier-Montaigne, Rokkan, S. (1970). Citizens, Elections, Parties. New York: McKay. Rueda, D. (2007). Social Democracy Inside Out. Oxford: Oxford University Press Rydgren, J. (2012) Class politics and the Radical Right, London, Routledge. 
Saraceno, C. (1994) The ambivalent familism of the Italian welfare state, Social Politics, I, 6082.

Saraceno, C. (2002) Social Assistance Dynamics in Europe. Bristol: The Policy Press.

World Bank (2013) Who is inactive, unemployed or needy? Assessing Post-Crisis policy options, World Bank, Washington D.C.

Zasova A. and Zdanovica A. (2014), Equity and Efficiency in the Latvian Tax-Benefit System, Euromod Policy Brief Series. 